\title{
Statement of Work for Services Provided by the Waste Sampling and Characterization Facility for the Effluent and Environmental Monitoring Program During Calendar Year 1998
}

Prepared for the U.S. Department of Energy

Assistant Secretary for Environmental Management

$\$$ Fluor Daniel Hanford, Inc.

Hanford Management and integration Contractor for the

U.S. Department of Energy under Contract DE-AC-0696-RL13200

Approved for Public Release; Further Dissemination Unlimited 
LEGAL DISCLAMER

This report was prepared as an account of work sponsored by an agency of the United States Govemment. Neither the United States Government nor any agency thereof, nor any of their employees, not any of their contractors, subcontractors or their employees, makes any warranty, express or implied, or assumes any legal liability or responsibility for the accuracy, completeness, or any third party's use or the results of such use of any information, apparatus, product, or process disclosed, or represents that its use would not infringe privately owned rights. Reference herein to any specific commercial product, process, or service by trade name, trademark, manufacturer, or otherwise, does not necessarily constitute or imply its endorsement, recommendation, or favoring by the United Stetes Government or any agency thergof or its contractors or subcontractors. The views and opinions of authors expressed herein do not necessarily state or reflect those of the United States Government or any agency thereof.

This raport has been reproduced from the bast availeble copy. Avsilable in paper copy and microfiche.

Available to the U.S. Department of Energy and its contractors from U.S. Department of Energy Office of Scientific and Technical Information (OSTI)

P.O. Box 62

Oak Ridge, TN 37831

(615) $576-8401$

Avoilable to the public from the U.S. Department of Commerce National Technical information Service (NTIS)

5285 Port Royal Road

Springfield, VA 22161

(703) $487-4650$

Printed in the United States of Americe 


\section{INFORMATION RELEASE REQUEST PUBLIC DOCUMENT CHANGE/REVISION \\ (Short Form No. i)}

1. Base Document ID. Number: HNF-EP-0835-3

2. Base Document Title:

Statement of Work for Services Provided by the Waste Sampling and Characterization Facility for the Effluent and Environmental Monitoring Program During Calendar Year 1998

3. Change/Revision Number: Rev. 3

4. Change/Revision Date: $01 / 29 / 98$

5. Unclassified Category:* · UC - 630

6. Budget \& Reporting Code: * B\&R - EW03120100

$I$ verify this change/revision to the base document indicated above:

- Complies with the provisions of WHC-CM-3-4

- Contains no Limited-Use information

- Contains no classified or Applied Technology references

- Does not change the intent or meaning of the base document

- And, the base document itself is approved for public release.

7. Responsible Manager: E. M. Greager

MSIN: H6-36

Telephone Number: $376-3132$
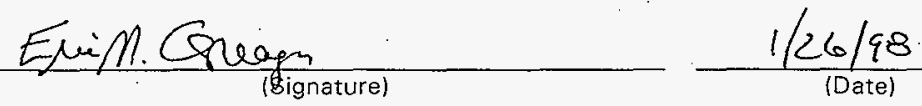
.

8. Information Release Administration Specialist: **

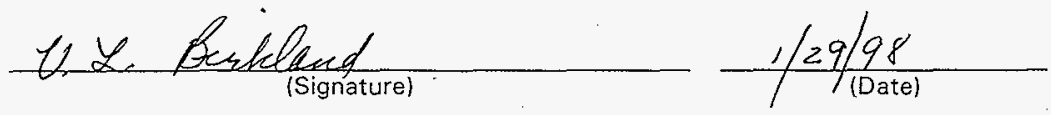

* Required only for full revisions transmitted to OSTI.

* * Required only for full revisions. 


\section{Statement of Work for Services Provided by the Waste Sampling and Characterization Facility for the Effluent and Environmental Monitoring Program During Calendar Year 1998}

B. P. Gleckler

Waste Management Federal Services of Hanford, Inc.

Date Published

January 1998

Prepared for the U.S. Department of Energy

Assistant Secretary for Environmental Management

Fluor Daniel Hanford, Inc.

P.O. Box 1000

Richland, Washington 


\section{RELEASE AUTHORIZATION}

\begin{tabular}{ll} 
Document Number: & HNF-EP-0835-3 \\
\hline Document Title: & $\begin{array}{l}\text { Statement of Work for Services Provided by the Waste } \\
\text { Sampling and Characterization Facility for the } \\
\text { Effluent and Environmental Monitoring Program During } \\
\text { Calendar Year } 1998\end{array}$
\end{tabular}

This document, reviewed in accordance with DOE Order 1430.1D, "Scientific and Technical Information Management," and DOE G 1430.1D-1, "Guide to the Management of Scientific and Technical Information," does not contain classified or sensitive unclassified information and is:

\section{APPROVED FOR PUBLIC RELEASE}

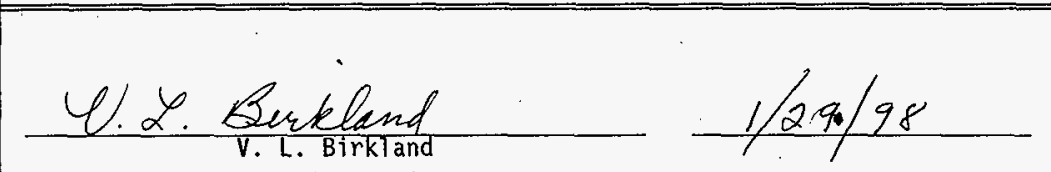

Lockheed Martin Services, Inc.

Document Control/Information Clearance

Reviowed for Applied Technology, Business Sensitive, Classifled, Copyrighted, Export Controlled, Patent, Personal/Private, Proprietary, Protected CRADA. Trademark, Unclessifiod Controlled Nuclear Information.

Trademark Disclaimer. Refarence herein to any specific commercial product, process, or senvice by trade name, trademark, manufacturer, of otherwise, does not necessarily constitute or imply its endorsement, recommendation, or favoring by the United States Govermment or any agency thereof or its contractors or subcontractors. The viewe and opinions of authors expressed herein do not necessarily state or reflect those of the United States Govemment or any agency thereof. This report has been reproduced from the best available copy.

Printed in the United States of America.

Available to the U.S. Department of Energy and its contractors from the U.S. Department of Energy Otfice of Scientific and Technical Information, P.O. Box 62, Oak Ridge, IN 37831; Tolephone: 423/576-8401.

Available to the public from the U.S. Dopartment of Commerce National Tachnical Information Senvice, 5285 Port Royal Road, Springtield, VA 22161; Telephone: 703/487-4650. 


\section{Document Title: STATEMENT OF WORK FOR SERVICES PROVIDED BY THE WASTE SAMPLING AND CHARACTERIZATION FACILITY FOR THE EFFLUENT AND ENVIRONMENTAI MONITORING PROGRAM DURING CALENDAR YEAR 1998}

Prepared by:

Approved by:

Approved by:

Approved by:

Approved by:

Reviewed by:

Reviewed by:

Reviewed by:

Reviewed by:

Reviewed by:

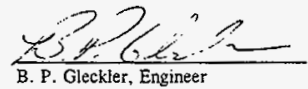

WMH Air \& Water Services

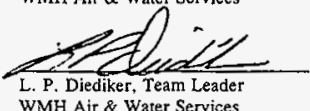

WMH Air \& Water Services

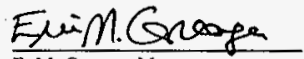

E. M. Greager, Manager

WMH Air \& Wrar Services

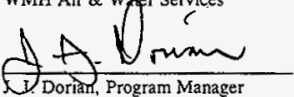

WMNW Environmental Monitoring \& Investigations

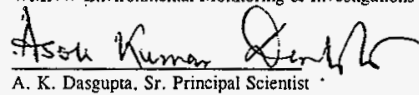

A. K. Dasgupta. Sr. Principal Scientist

WMH Low-Level Labs Radioanalytical Chemistry

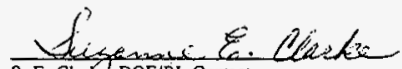

S. E. Clarko. DOE/RL Contact

DOE-RL Ehvironmental Assurance, Permits \& Policy

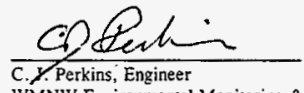

WMNW Environmental Monitoring \& Investigations

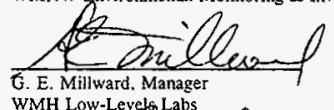

WMH Low-Levelk Labs

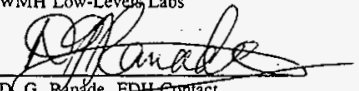

D G. Ranade-EDHeontact

FDH Environmental Integration

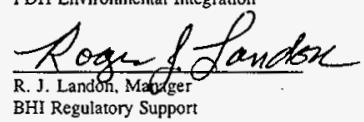

$\frac{1126-19 \overline{8}}{\text { Date }}$

$\frac{1-2<-98}{\text { Date }}$

$\frac{1 / 26 / 98}{\text { Date }}$

$\frac{1 / 27 / 98}{\text { Date }}$

$\frac{1 / 28 / 98}{\text { Date }}$

$\frac{4 / 28 / 98}{D+10}$

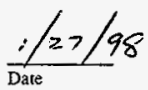

$1 / 28 / 98$

1/26/98

$\frac{1 / 281980}{\text { Date }}$ 


\section{HNF-EP-0835-3}

(This page intentionally left blank.) 
HNF-EP-0835-3

\section{TABLE OF CONTENTS}

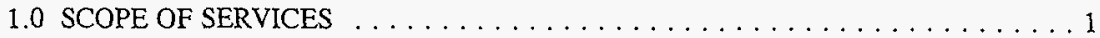

2.0 REGULATORY REPORTING REQUIREMENTS $\ldots \ldots \ldots \ldots \ldots \ldots \ldots \ldots$

2.1 Radionuclide Air Emissions Report for the CLEAN AIR ACT . . . . . 1

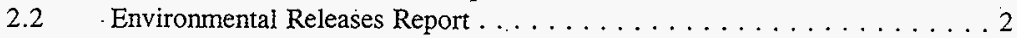

2.3 Hanford Site Environmental Report . . . . . . . . . . . . 2

2.4 Effluent Information System-onsite Discharge Information System Report . . 2

2.5 Hanford Site Near-Facility Environmental Monitoring Annual Report . . . . 2

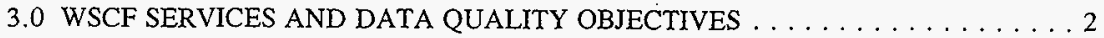

3.1 Sample and Analysis Requirements $\ldots \ldots \ldots \ldots \ldots \ldots \ldots \ldots$

3.2 Composite Sample Requirements . . . . . . . . . . . . 3

3.3 Year-end Data Reporting Due Dates . . . . . . . . . . . . . . 3

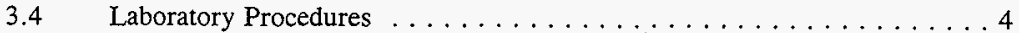

3.5 Quality Control . . . . . . . . . . . . . . . . . 4

3.6 Retention of and Access to Raw Data and Results . . . . . . . . . . . 6

3.7 Analytical Error \& Minimum Detectable Concentration . . . . . . . . 6

3.8 Routine Electronic Transfer of Analytical Data . . . . . . . . . . . 6

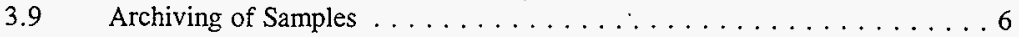

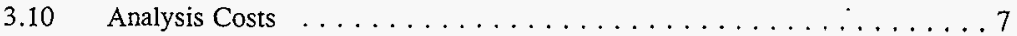

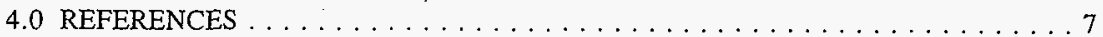

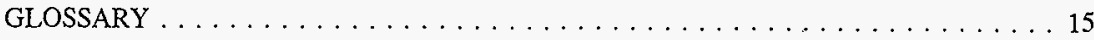

APPENDIX $\ldots \ldots \ldots \ldots \ldots \ldots \ldots \ldots \ldots \ldots \ldots \ldots \ldots \ldots \ldots \ldots \ldots \ldots \ldots$

DISTRIBUTION $\ldots \ldots \ldots \ldots \ldots \ldots \ldots \ldots \ldots \ldots \ldots \ldots \ldots \ldots \ldots \ldots$ DISTR-1 


\section{HNF-EP-0835-3}

\section{LIST OF TABLES}

1 Ambient and Effluent Air Sample Analysis Criteria for WSCF . . . . . . . . . . 9

2 Groundwater Monitoring and Liquid Effluent Sample Analysis Criteria for WSCF . . . . . . . . . . . . . . . . . . . . . . 10

3 Pond Vegetation and Sediment Sample Analysis Criteria for WSCF . . . . . . . . 11

4 Nonroutine Environmental Sample Analysis Criteria for WESF . . . . . . . . . . . 12

5 Matrix for Charging Sample Analysis Costs . . . . . . . . . . . . . . . 13

6 Additional Services Factored into WSCF's Sample Analysis Prices for EEM Program . . . . . . . . . . . . . . . . . . . . . . . 14

A1 Air Samples Receiving "Continuous" Routine Analyses by WSCF

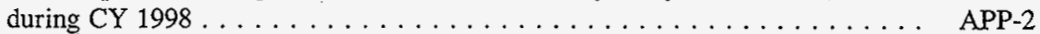

A2 Archived Samples Requiring a Total Alpha/Beta Analysis by WSCF during CY $1998 \ldots \ldots \ldots \ldots$. . . . . . . . . . . . . . . . . . . . . . APP-3

A3 Near-Facility Monitoring CY 1998 Sample Analyses per Year . . . . . . . . . APP AP 


\section{STATEMENT OF WORK FOR SERVICES PROVIDED BY THE WASTE SAMPLING AND CHARACTERIZATION FACILITY FOR THE EFFLUENT AND ENVIRONMENTAL MONITORING PROGRAM DURING CALENDAR YEAR 1998}

\subsection{SCOPE OF SERVICES}

This document defines the services the Waste Sampling \& Characterization Facility (WSCF) shall provide the Effiuent and Environmental Monitoring Program (EEM) throughout the calendar year for analysis. The purpose of the EEM Program is to monitor liquid and gaseous effluents, and the environment immediately around the facilities which may contain radioactive and hazardous materials. Monitoring data are collected, evaluated, and reported to determine their degree of compliance with applicable federal and state regulations and permits.

The Appendix identifies the samples EEM plans to submit for analysis in CY-1998. Analysis of effluent (liquid and air discharges) and environmental (air, liquid, animal, and vegetative) samples is required using standard laboratory procedures, in accordance with regulatory and control requirements cited in Quality Assurance Program Plan for Radionuclide Airborne Emissions Monitoring (especially Appendix G) (WHC 1995a), Effluent Monitoring Quality Assurance Project Plan for Radionuclide Airborne Emissions Data (WHC 1995b), Near-Facility Environmental Monitoring Quality Assurance Project Plan (WMNW 1997), and Hanford Analytical Services Quality Assurance Requirements Documents (DOE 1996). Should changes to this document be necessary, WSCF or the Waste Management Federal Services, Inc. (WMH) Air \& Water Services (AWS) Organization may amend it an any time with a jointly approved internal memo.

\subsection{REGULATORY REPORTING REQUIREMENTS}

It is essential for the WSCF to meet the due dates specified. The analytical data required by those due dates are necessary to maintain compliance with environmental release reporting commitments mandated by regulatory agencies and the U.S. Department of Energy (DOE). Variances to technical criteria or due dates in this document must be documented by the WSCF and approved or acknowledged by AWS.

\subsection{Radionuclide Air Emissions Report for the CLEAN AIR ACT}

This report documents radionuclide air emissions from the Hanford Site and the resulting effective dose equivalent to any member of the public from those emissions. This report 
complies with the reporting requirements of the Code of Federal Regulations, Title 40, "Protection of the Environment," Part 61, "National Emissions Standards for Hazardous Air Pollutants," Subpart H, "National Emission Standards for Emissions of Radionuclides Other Than Radon From Department of Energy Facilities". (40 CFR 61 Subpart H) and Chapter 246247 of the Washington Administrative Code (WAC 246-247).

\subsection{Environmental Releases Report}

The purpose of this report is to fulfill the effluent discharge reporting requirements of DOE Order 5400.1 and to summarize the compliance status of effluent releases from PHMC and ERC facilities.

\subsection{Hanford Site Environmental Report}

Pacific Northwest National Laboratory annually compiles and publishes this report for DOE, in compliance with DOE Order 5400.1. AWS and the Waste Management Federal Services, Inc., Northwest Operations (WMNW) Environmental Monitoring \& Investigations Organization (EMI) provide the effluent and near-facility monitoring sections of this report.

\subsection{Effluent Information System-onsite Discharge Information System Report}

Each year AWS compiles and transmits this report electronically, for all Hanford contractors, to Idaho National Engineering Laboratory in Idaho Falls for inclusion in the Effluent Information System/Onsite Discharge Information System (EIS/ODIS) database, in compliance with DOE Order 5484.1.

\subsection{Hanford Site Near-Facility Environmental Monitoring Annual Report}

EMI publishes this report annually, for the EEM program. The report provides a yearly summary of sampling and analysis of soil, vegetation, ambient air, etc. near Hanford facilities. This monitoring is performed in accordance with 40 CFR 61 Subpart H, WAC 246-247, DOE Order 5400.1, and DOE Order 5820.2A requirements.

\subsection{WSCF SERVICES AND DATA QUALITY OBJECTIVES}

WSCF shall provide the following analytical services when analyzing low-level effluent and environmental samples from EEM. 


\subsection{Sample and Analysis Requirements}

All services necessary shall be provided to complete the analytical requirements listed in Tables 3 through 7. Analyses shall be performed in accordance with applicable requirements and procedures contained in the references listed in section 1.0 above. Analytical results shall be expressed in the units shown for the respective minimum detectable concentrations (MDC) in the tables.

\subsection{Composite Sample Requirements}

Effluent air emission composite samples shall be composited quarterly or monthly and the first three quarters shall be reported electronically to AWS by the dates listed below:

- First quarter air emission composite results . . . . . . . . . . June 30, 1998

- Second quarter air emission composite results . . . . . . . . September 30, 1998

- Third quarter air emission composite results . . . . . . . . . December 31, 1998

All results shall be in units of concentration.

Ambient air composite samples shall be composited bi-annually and reported electronically to EMI within 90 days of receiving all samples and data for compositing. All results shall be in units of concentration, unless otherwise specified.

\subsection{Year-end Data Reporting Due Dates}

The due dates for submission of year-end analysis results to AWS for all samples collected up through December 31st are:

- Air emission data . . . . . . . . . . . . . . . February 15, 1999

The due dates for submission of year-end analysis results to EMI for all samples collected up through December 31st are:

- Environmental data

(air, surface water, and pond vegetation and sediment) $\ldots \ldots$ March 15, 1999

All results shall be transmitted electronically and shall be in units of concentration, unless otherwise specified. The analysis results from any weekly, biweekly, or monthly sample collected on or after January 1st of the succeeding new year will be applied to that year. 


\subsection{Laboratory Procedures}

Use laboratory analytical procedures that are:

- In compliance with EPA Method 114, Section 4.0, "Quality Assurance Methods," 40 CFR Part 61, Appendix B (specifically, 4.4 and 4.5), and applicable requirements and procedures contained in the references listed in Section 1.0 above.

- In compliance with Chapter 6.0 of the Environmental Regulatory Guide for Radiological Effluent Monitoring and Environmental Surveillance document (DOE 1991).

- In compliance with the requirements specified in the Hanford Analytical Services Quality Assurance Requirements Documents (DOE 1996)

- Appropriate to the sample medium and size and the analysis requirements listed in Tables 1 through 4.

\subsection{Quality Control}

WSCF shall assure the integrity and validity of analytical test results through implementation of an internal quality control program. Standard methods shall be used whenever possible and methods that are developed or adapted shall be tested and completely documented.

Calibration and quality controls methods shall be performed using methods consistent with the Hanford Analytical Services Quality Assurance Requirements Documents (DOE 1996). WSCF shall provide data biannually to AWS, which demonstrates that the data quality objectives for accuracy, precision, and completeness have been.met. Audit able quality control (QC) test results shall be provided within two weeks of requesting specific records, without any additional charges. As a special request, audit able quality control (QC) test results can be provided in less than two weeks (e.g. within 24 hours, etc...), upon receiving a request for specific records. Special requests may require additional resources and funding, which is the responsibility of the requestor to provide.

WSCF shall participate in the U.S. DOE Environmental Measurements Laboratory (EML) inter-comparison program, as required per DOE/EH-0173T (DOE 1991). WSCF shall participate in all U.S. EPA laboratory inter-comparison programs, applicable to the analyses being performed. EML and EPA laboratory inter-comparison results shall be provided annually. 


\subsubsection{Water, Vegetation, and Soil Sample Analyses}

The QC tests shall be for accuracy, precision, and completeness. The results of all QC tests shall be documented. Analytical problems identified through analysis of QC samples shall be promptly corrected. WSCF shall produce a minimum of $90 \%$ usable and valid analytical data, for all EEM-related samples received. WSCF shall provide data to AWS, which demonstrates that the accuracy, precision, and completeness objectives have been met, biannually.

WSCF shall prepare and analyze laboratory control standards (LCSs), blank and duplicate samples to verify the accuracy and precision of all radiochemical methods. The total number of all QC samples shall be no less than $10 \%$ of all ordered sample analyses. The LCSs shall be included with each batch of samples processed and have, insofar as possible, a matrix, volume, mass, and other relevant characteristics of the actual samples being analyzed. The LCSs shall have range of activity from five (5) times to no greater than twenty (20) times the MDC values in Tables 1 through 4.

Method accuracy requirements shall be met when $95 \%$ of the LCS results, fall within $\pm 25 \%$. Precision requirements shall be met when duplicate results, for samples $\geq 5$ times the MDC values in Tables 1 through 4 or when the analytical uncertainty is $\leq 20 \%$, fall within $\pm 30 \%$ relative percent difference.

\subsubsection{Air Sample Analyses}

The QC tests shall be for accuracy, precision, and completeness. The results of all QC tests shall be documented. Analytical problems identified through analysis of QC samples shall be promptly corrected. WSCF shall produce a minimum of $90 \%$ usable analytical data, for all EEM-related samples received. WSCF shall provide data to AWS, which demonstrates that the accuracy, precision, and completeness objectives have been met, biannually.

Accuracy requirements shall be met when $95 \%$ of the results from counting instrument performance check standards, fall within $\pm 25 \%$. Precision of air sample data shall be evaluated by recounting a portion of the samples analyzed, since the creation of duplicate samples is not feasible for air sampies. AWS will identify the samples to be used for precision analysis on a quarterly basis. A minimum of $10 \%$ of the samples analyzed, in which the sample results will be used for calculating effluent emissions, will be recounted to determine precision, approximately 70 samples. Precision requirements shall be met when samples, with activities 25 times the MDC values in Tables 1 through 4 or when the analytical uncertainty is $\leq 20 \%$, fall within $\pm 30 \%$ relative percent difference.

The requirements of Section 3.5.1 apply to air samples analyses which involve radiochemical separations. The data quality objectives, for air samples requiring radiochemical separations, shall be met when the objectives in specified in Section 3.5.1 are met. 


\subsection{Retention of and Access to Raw Data and Results}

All raw data and analytical results shall be retained as quality assurance documents for a minimum period of 5 years, as specified by 40 CFR 61 Subpart $H$.

As needed, EEM shall have access to all available raw data and results related to EEM samples. WSCF shall provide analysis printouts upon request (e.g. GEA list of identified peaks).

\subsection{Analytical Error \& Minimum Detectable Concentration}

WSCF shall provide the overall analytical error associated with each analytical result. Total analytical error shall be calculated at the $95 \%$ confidence interval.

WSCF shall ensure that the sample's MDC does not exceed the values specified in Tables 1 through 4 , when the nominal sample volume is provided. WSCF will not be accountable for maintaining the MDC limits when samples less than the nominal sample volume are provided. When sample sizes are less than or greater than the nominal volumes specified in Tables 1 through 4, EEM may adjust the MDCs for samples by multiplying the specified MDC by the ratio of the actual sample size and the nominal sample size.

\subsection{Routine Electronic Transfer of Analytical Data}

WSCF shall routinely and electronically transmit all analytical results to AWS and EMI, via the ABCASH database. WSCF shall electronically transmit all calendar-year 1998 data to AWS by February 22, 1999 and to EMI by March 15, 1999.

\subsection{Archiving of Samples}

Ambient air monitoring samples shall be archived upon the completion of the total $\alpha$ and $\beta$ analysis. Archived ambient air samples will be composited and analyzed bi-annually by WSCF. These samples can be identified as the samples with the Nxxx series Electronic Data Processing (EDP) codes.

Effluent air samples with EDP Codes listed in the Table A2 of the Appendix, shall be archived prior to any analyses being performed. Upon receipt, WSCF will sort effluent samples into samples to be analyzed and samples to be archived, regardless of any labeling on the samples. WSCF shall enter the sample collection data into ABCASH, when samples with EDP codes listed in Tables A1 and A2 have not been entered into ABCASH by the facility. After each quarter, AWS will provide specific analysis instructions to WSCF regarding the archived samples. All archived effluent air samples, from CY-1998, may be disposed of after July 15, 1999. 
Backup record and effluent Continuous Air Monitor (CAM) air samples shall not be analyzed but shall be archived until July 15, 1999. These samples can be identified as the samples received in white envelopes stamped "Archive Only", with EDP codes that are not listed in the Appendix.

\subsection{Analysis Costs}

The sample analysis costs provided in Tables 1 through 4 . These prices contain additional fees associated with services specific to the EEM Program. Table 6 contains a detailed list of the additional services factored into unit prices. The analysis costs in Tables 1 through 2 are estimated and may fluctuate due to changes in prices and workscope. Adjustments made to sample analysis costs shall have the concurrence of EEM. Table 5 provides a matrix to assist in charging analysis costs to the appropriate cost account.

\subsection{REFERENCES}

40 CFR 61 Subpart H, Code of Federal Regulations, Title 40, "Protection of the Environment, " Part 61, "National Emissions Standards for Hazardous Air Pollutants," Subpart H. "National Emission Standards for Emissions of Radionuclides Other Than Radon From Department of Energy Facilities", as amended, U.S. Environmental Protection Agency, Washington, D.C.

40 CFR 61 Appendix B, Code of Federal Regulations, Title 40, "Protection of the Environment, " Part 61, "National Emissions Standards for Hazardous Air Pollutants," Appendix B, "Quality Assurance Methods," as amended, Appendix B, U.S. Environmental Protection Agency, Washington, D.C.

ASTM, 1991, Establishing a Measurement System Quality Control Program for Analytical Chemistry Laboratories Within the Nuclear Industry, ASTM C 1210, American Society for Testing and Materials.

DOE, 1988a, General Environmental Protection Program, DOE Order 5400.1, U.S. Department of Energy, Washington, D.C.

DOE, 1988b, Radioactive Waste Management, DOE Order 5820.2A, U.S. Department of Energy, Washington, D.C.

DOE, 1983, Environmental Protection, Safety and Health Protection Information Reporting Requirements, DOE Order 5484.1, U.S. Department of Energy, Washington D.C. 
DOE, 1991, Environmental Regulatory Guide for Radiological Effluent Monitoring and Environmental Surveillance, DOE/EH-0173T, U.S. Department of Energy, Washington D.C.

DOE, 1996, Hanford Analytical Services Quality Assurance Requirements Documents, DOE/RL-96-68, U.S. Department of Energy, Richland, Washington.

HPS, 1996, Performance Criteria for Radiobioassay, HPS N13.30, an American National Standard, Health Physics Society, McLean, Virginia.

WAC 246-247, Washington Administrative Code Chapter 246-247, "Radiation Protection - Air Emissions," as amended, Washington Department of Health, Olympia, Washington.

WHC-CM-7-5, Environmental Compliance, Westinghouse Hanford Company, Richland, Washington.

WHC, 1994, Quality Assurance Project Plan for Facility Effluent Monitoring Plan Activities, WHC-EP-0446 Revision 2, Westinghouse Hanford Company, Richland, Washington.

WHC, 1995a, Quality Assurance Program Plan for Radionuclide Airborne Emissions Monitoring, WHC-EP-0536 Revision 3, Westinghouse Hanford Company, Richland, Washington.

WHC, 1995b, Effluent Monitoring Quality Assurance Project Plan for Radioactive Airborne Emissions Data, WHC-EP-0528 Revision 2, Westinghouse Hanford Company, Richland, Washington.

WMNW, 1997, Near-Facility Environmental Monitoring Quality Assurance Project Plan, HNF-EP-0538 Revision 3, Waste Management Federal Services, Inc. Northwest Operations, Richland, Washington. 
Table 1.

Ambient and Effluent Air Sample Analysis Criteria for WSCF.

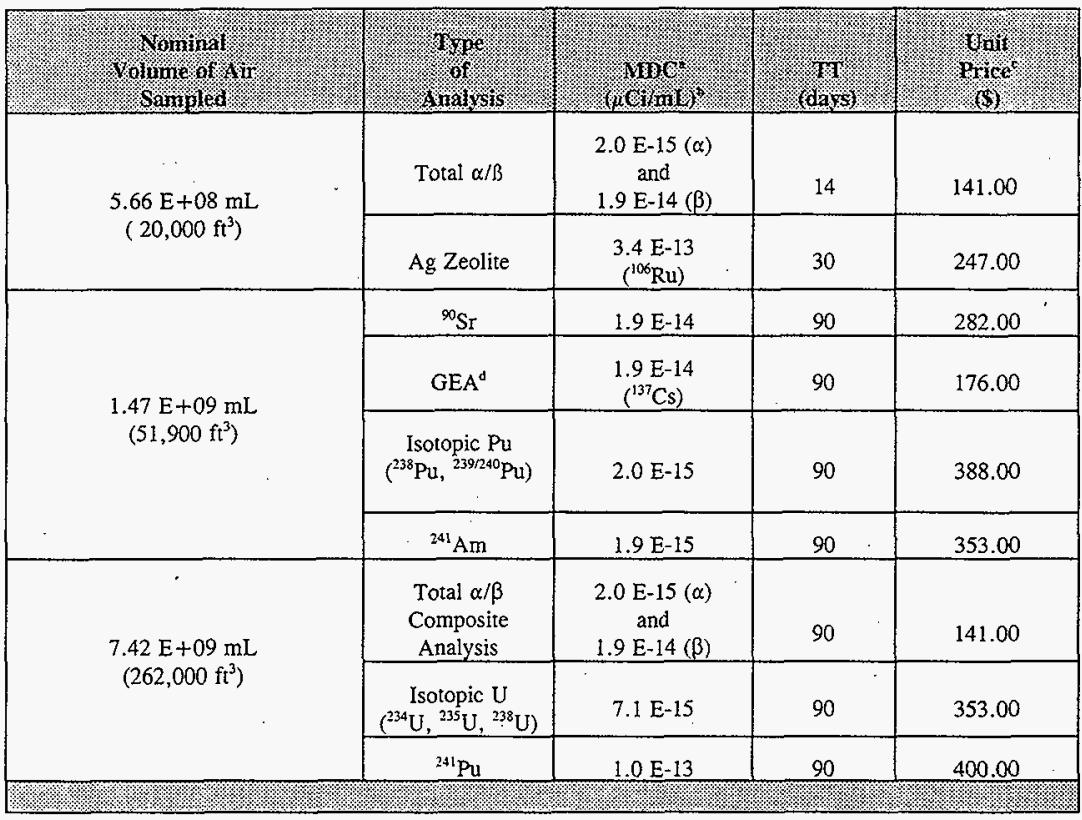

MDC = Minimum Detectable Concentration

$\mathrm{TT}=$ Turnaround Time, starting from the receipt of all samples to be anlalyzed and all relevant sampling data, ending when the results, in units of concentration, are received electronically.

a MDC's shall be as low as reasonably attainable, but shall not exceed the values specified in the table. MDC values obtained from 40 CFR 61 Appendix E Table II.

b Unless other units of measure are indicated.

c These prices contain additional fees associated with services specific to the EEM Program. Table 8 contains a detailed list of the additional services factored into unit prices.

d All positive GEA results shall be reported, with the exception of the short-lived ${ }^{2 \pm} \mathrm{Rn}$ and ${ }^{220} \mathrm{Rn}$ progeny. 
Table 2.

Groundwater Monitoring and Liquid Effluent Sample Analysis Criteria for WSCF ${ }^{a}$.

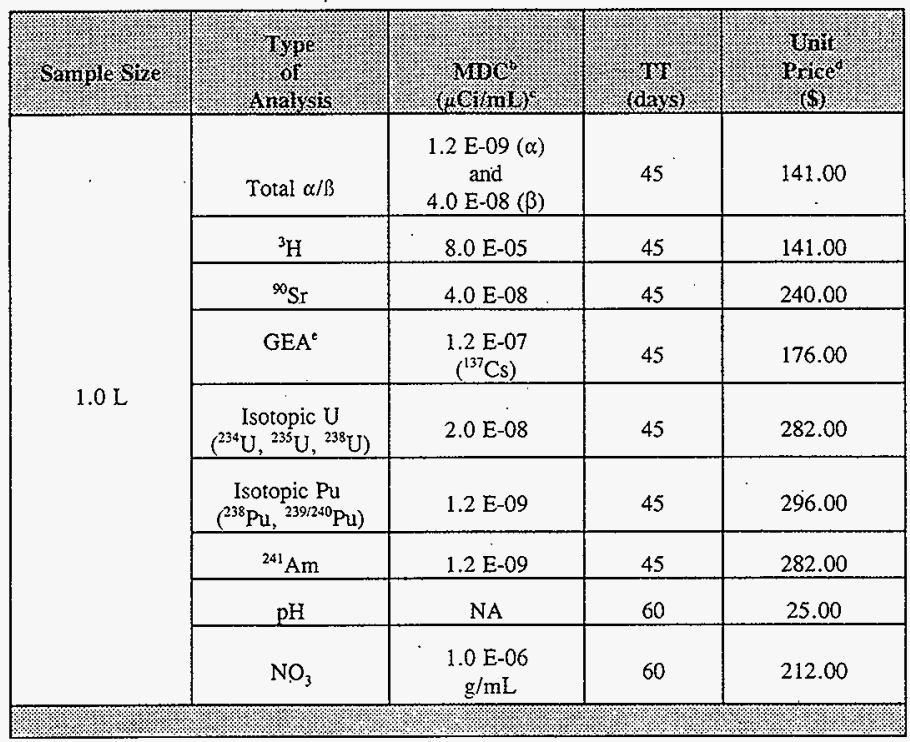

MDC = Minimum Detectable Concentration

$T T=$ Turnaround Time, starting from the receipt of all samples to be analyzed and all relevant sampling data. and ending when the results, in units of concentration, are received electronically.

a Liquid effluent samples shall be analyzed unfiltered, where as ground water samples shall be filtered and only the filtrate analyzed. The EDP codes for the liquid effluent samples are identified in memo 88420-94-130's Attachment.

b MDC's shall be as low as reasonably atrainable, but shall not exceed the values specified in the table. MDC values obtained from $4 \%$ of the Derived Concentration Guidelines (DCG).

c Unless other units of measure are indicated.

d These prices contain additional fees associated with services specific to the EEM Program. Table 8 contains a detailed list of the additional services factored into unit prices. 
Table 3.

Pond Vegetation and Sediment

Sample Analysis Criteria for WSCF.

\begin{tabular}{|c|c|c|c|c|}
\hline samplestro & 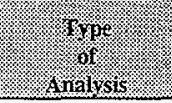 & 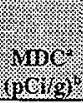 & 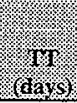 & 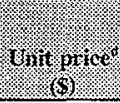 \\
\hline 500 & ${ }^{\infty} \mathrm{Sr}$ & 10.00 & 90 & 318.00 \\
\hline 500 & $\mathrm{GEA}^{d}$ & $\begin{array}{c}0.20 \\
\left({ }^{137} \mathrm{Cs}\right) \\
\end{array}$ & 90 & 205.00 \\
\hline 500 & $\begin{array}{c}\text { Isotopic } \mathrm{U}^{235} \\
\left({ }^{234} \mathrm{U},{ }^{235} \mathrm{U},{ }^{238} \mathrm{U}\right)\end{array}$ & 0.04 & 90 & 388.00 \\
\hline 500 & $\begin{array}{c}\text { Isotopic } \mathrm{Pu} \\
\left({ }^{238} \mathrm{Pu},{ }^{239 / 240} \mathrm{Pu}\right)\end{array}$ & 1.00 & 90 & 388.00 \\
\hline
\end{tabular}

$\mathrm{MDC}=$ Minimum Detectable Concentration

TT = Turnaround Time, starting from the receipt of all samples to be analyzed and all relevant sampling data, and ending when the results, in units of concentration, are received electronically.

a MDC's shall be as low as reasonably attainable, but shall not exceed the values specified in the table.

b Uniess other units of measure are indicated

c All positive GEA results shall be reported, with the exception of the short-lived ${ }^{232} \mathrm{Rn}$ and ${ }^{220} \mathrm{Rn}$ progeny.

d These prices contain additional fees associated with services specific to the EEM Program. Table 8 contains a detailed list of the additional services factored into unit prices.

e Total uranium analyses will be performed until an isotopic uranium analysis is established. 
Table 4.

Nonroutine Environmental Samples, Sample Analysis Criteria for WSCF ${ }^{2}$.

\begin{tabular}{|c|c|c|c|c|}
\hline 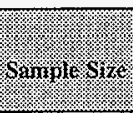 & 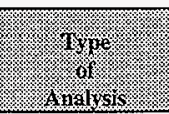 & M19 & 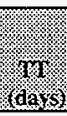 & asco \\
\hline \multirow{4}{*}{ TBD } & ${ }^{\infty} \mathrm{Sr}$ & TBD & 90 & TBD \\
\hline & $\mathrm{GEA}^{d}$ & TBD & 90 & TBD \\
\hline & $\begin{array}{c}\text { Isotopic U } \\
\left({ }^{234} \mathrm{U},{ }^{235} \mathrm{U},{ }^{238} \mathrm{U}\right)\end{array}$ & TBD & 90 & TBD \\
\hline & $\begin{array}{c}\text { Isotopic } \mathrm{Pu} \\
\left({ }^{238} \mathrm{Pu},{ }^{239 / 240} \mathrm{Pu}\right)\end{array}$ & TBD & 90 & TBD \\
\hline
\end{tabular}

MDC $=$ Minimum Detectable Concentration

TT = Turnaround Time, starting from the receipt of all samples to be analyzed and all relevant sampling data, and ending when the results, in units of concentration, are received electronically.

$\mathrm{TBD}=\mathrm{To}$ Be Determined

a Occasional nonroutine air, liquid, vegetation, and sediment samples may need analysis. WSCF can not accept the following types of nonroutine samples: animals, feces, nests, or samples with an exposure rate $>1 \mathrm{mR} / \mathrm{h}$, and/or samples containing $>10 \mathrm{nCi}$ of any alpha emitter.

b MDC values and units for nonroutine samples shall be dependent on sample type and commensurate with the values listed in Tables 1 through 3 . MDC's shall be as low as reasonably attainable, but shall not exceed the values specified in the Tables 1 through 3 .

c Cost for nonroutine samples shall be dependent on sample type and commensurate with the values listed in Tables 3 through 5 .

d All positive GEA results shall be reported, with the exception of the short-lived ${ }^{22-} \mathrm{Rn}$ and ${ }^{120} \mathrm{Rn}$ progeny. 
Table 5.

Matrix for Charging Sample Analysis Costs.

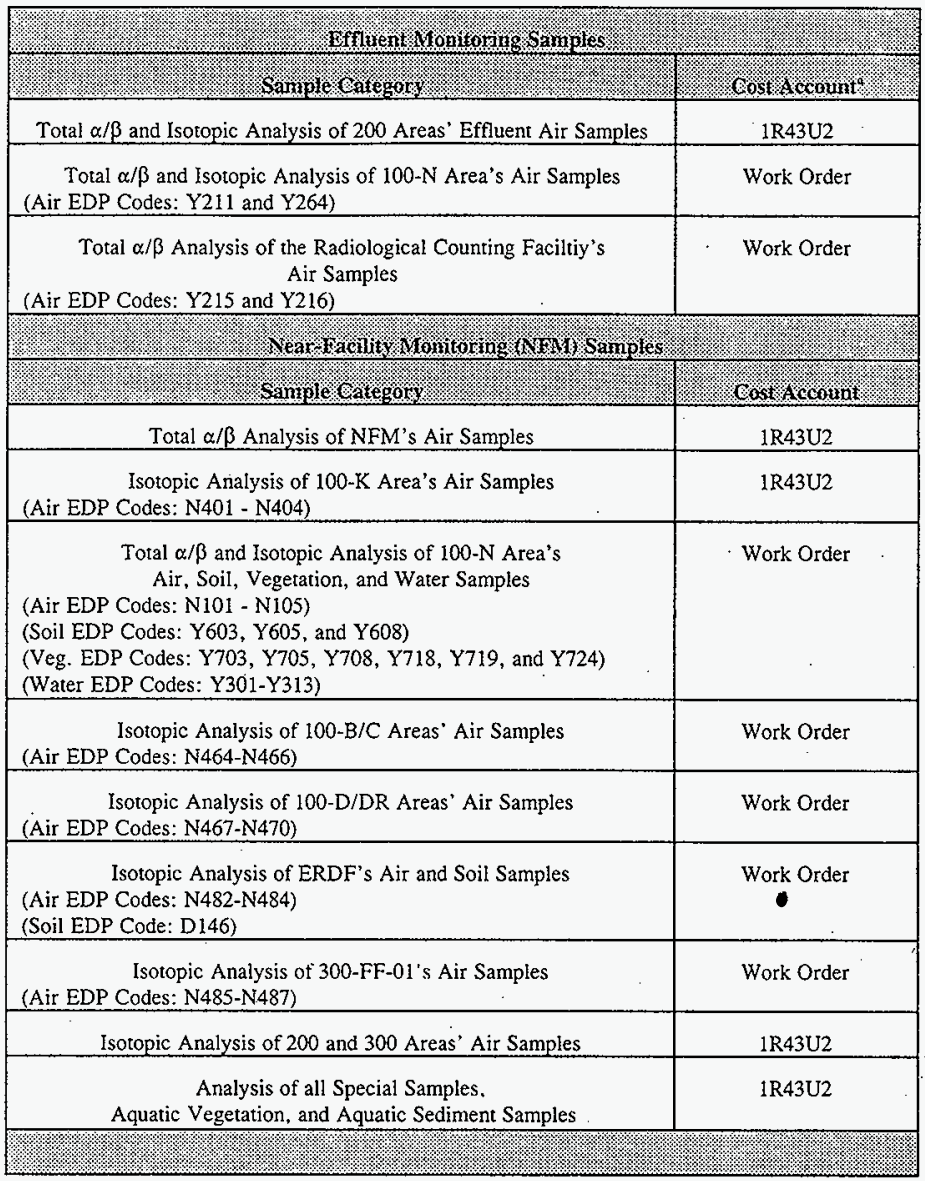

a TCPNs and work order numbers will not be included in this document, but will be provided to WSCF. 
Table 6.

Additional Services

Factored into WSCF's Sample Analysis Prices for EEM Program.

\begin{tabular}{|c|c|}
\hline 稵ogor & 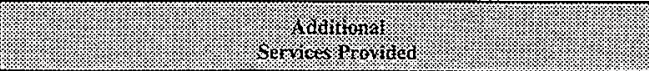 \\
\hline \multirow{10}{*}{$\begin{array}{l}\text { Air } \\
\text { Samples }\end{array}$} & $\begin{array}{l}\text { Entering sample collection data into } \mathrm{ABCASH} \text {, for facilities not equipped } \\
\text { with bar coding equipment. }\end{array}$ \\
\hline & Downloading all air sample results into ABCASH. \\
\hline & Disposal of samples and wastes from chemical processing. \\
\hline & $\begin{array}{l}\text { Archiving NFM samples and effuent samples from major emission units, } \\
\text { which receive composite analyses. }\end{array}$ \\
\hline & $\begin{array}{l}\text { Archiving samples from minor emission units, which receive quarterly. } \\
\text { analysis. }\end{array}$ \\
\hline & $\begin{array}{l}\text { Archiving backup effluent samples and effluent samples from minor } \\
\text { emission units, which do not get analyzed. }\end{array}$ \\
\hline & Notifying EEM POCs about zero ABCASH results. \\
\hline & $\begin{array}{l}\text { Sorting effluent samples into two groups: 1) samples to be analyzed and 2) } \\
\text { samples to be archived. }\end{array}$ \\
\hline & Assembly and preparation of samples for composite analysis. \\
\hline & $\begin{array}{l}\text { Preparation and analysis of QC samples (e.g. control standards, blanks. } \\
\text { duplicates, matrix spikes, etc....). }\end{array}$ \\
\hline \multirow{5}{*}{$\begin{array}{l}\text { Liquid } \\
\text { Samples }\end{array}$} & Archiving samples until composite analysis is performed. \\
\hline & Archiving unused samples until EEM reports are issued. \\
\hline & $\begin{array}{l}\text { Assembly and preparation of samples for composite analysis. Includes } \\
\text { verifying receipt of all samples for composite, calculating effluent tream } \\
\text { volumes and determining aliquot sizes for composite. }\end{array}$ \\
\hline & Disposal of samples and wastes from chemical processing. \\
\hline & $\begin{array}{l}\text { Preparation and analysis of QC samples (e.g. control standards, blanks, } \\
\text { duplicates. matrix spikes, etc...). }\end{array}$ \\
\hline & 样 \\
\hline \multirow{4}{*}{ Miscellaneous } & Supporting audits of the EEM Program. \\
\hline & Participate in the prescribed laboratory intercomparison programs. \\
\hline & Provide laboratory intercomparison results to EEM. \\
\hline & Perform rush and emergency sample analyses. \\
\hline
\end{tabular}


HNF-EP-0835-3

\section{GLOSSARY}

\section{ACRONYMS}

$\begin{array}{ll}\text { AWS } & \text { WMH's Air \& Water Services Organization } \\ \text { CAM } & \text { Continuous Air Monitor } \\ \text { DOE } & \text { U.S. Department of Energy } \\ \text { DOE-RL } & \text { U.S. Department of Energy, Richland Operations } \\ \text { EDP Code } & \text { Electronic Data Processing Code } \\ \text { EIS-ODIS } & \text { Effluent Information System-Onsite Discharge Information System } \\ \text { EEM } & \text { Effluent and Environmental Monitoring Program } \\ \text { EMI } & \text { WMNW's Environmental Monitoring \& Investigations Organization } \\ \text { EML } & \text { Environmental Measurements Laboratory } \\ \text { EPA } & \text { U.S. Environmental Protection Agency } \\ \text { GEA } & \text { Gamma Energy Analysis } \\ \text { LCS } & \text { Laboratory Control Standards } \\ \text { MDC } & \text { Minimum Detectable Concentration } \\ \text { NFM } & \text { Near-Facility Monitoring } \\ \text { PHMC } & \text { Project Hanford Management Contractor } \\ \text { TT } & \text { Turnaround Time } \\ \text { TBD } & \text { To Be Determined } \\ \text { WAC } & \text { Washington Administrative Code } \\ \text { WMH } & \text { Waste Management Federal Services of Hanford, Inc. } \\ \text { WMNW } & \text { Waste Management Federal Services Northwest, Inc., Northwest Operations } \\ \text { WSCF } & \text { Waste Sampling and Characterization Facility }\end{array}$

\section{DEFINITION OF TERMS}

Accuracy. The degree of agreement of a measurement with a true or known value.

Completeness. A measure of the amount of valid and usable data obtained from a measurement system compared to the amount that was expected to be obtained under correct normal conditions.

Precision. A measure of mutual agreement among individual measurements of the same property under similar conditions. Precision is best expressed in terms of standard deviation.

Turnaround time. Elapsed time, in days, starting from the receipt of all samples to be analyzed and all relevant sampling data, and ending when the results, in units of concentration, are received electronically. 


\section{HNF-EP-0835-3}

(This page intentionaliy left blank.) 
HNF-EP-0835-3

\section{APPENDIX}

\section{Analytical Requirements}

for

EEM Sampling During CY 1998 
Table A1

Air Samples Receiving "Continuous" Routine Analyses

by WSCF during CY 1998

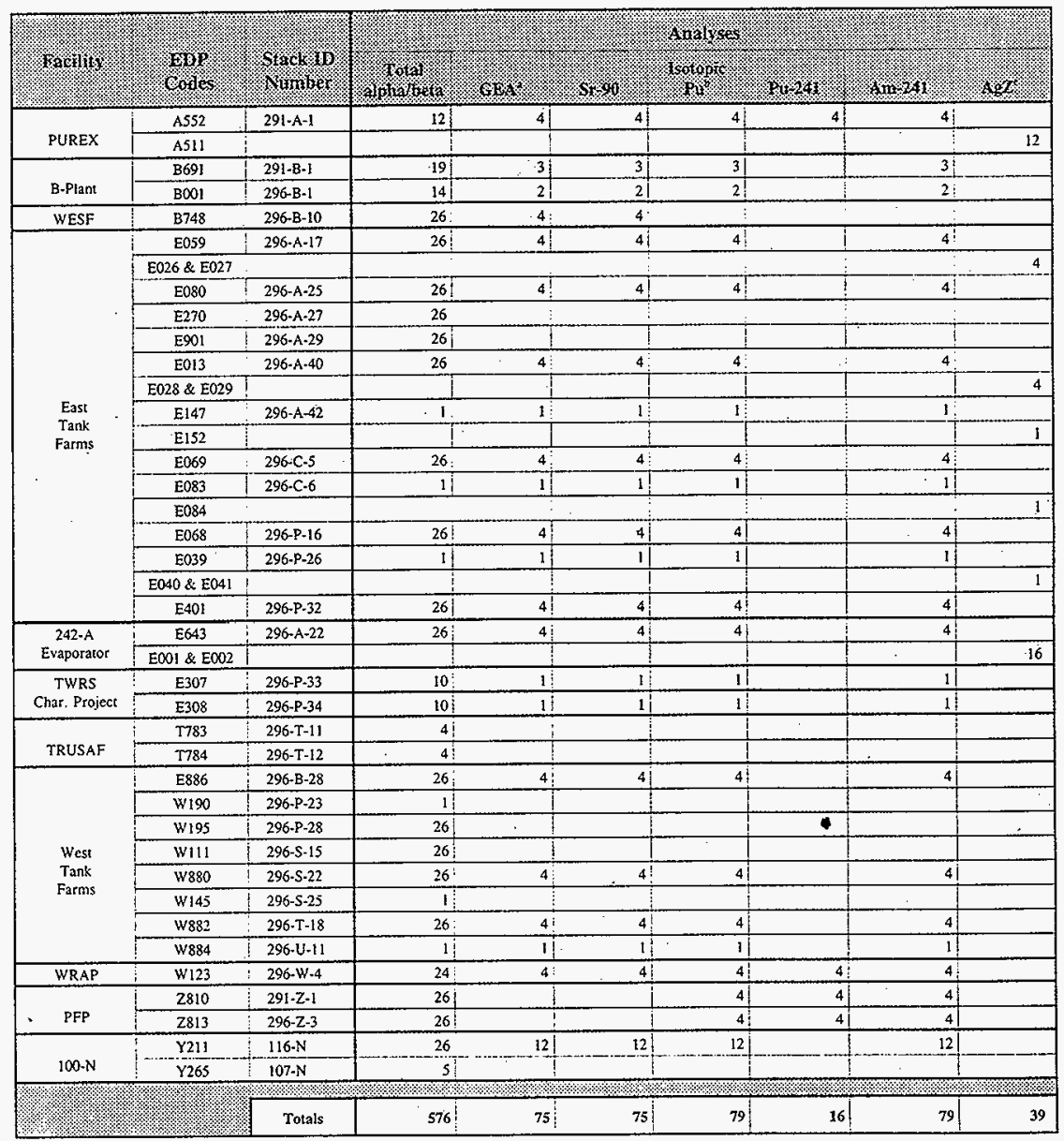

Minimum GEA analysis will be for Co-60. Ru-106, Sn-113, Sb-125, Cs-134, Cs-137, Eu-152, Eu-154; and Eu-155. All positive GEA results shall be reported also.

b Air \& Water Services will provide explicit instructions on the composited analyses of these samples

c AgZ analysis includes Ru-106, Sn-113, Sb-125, and I-129. 
Table A2

Archived Samples Requiring Total Alpha/Beta Analyses $^{2}$ by WSCF during CY 1998

\begin{tabular}{|c|c|c|c|c|}
\hline maju & 3ox & Stank & 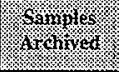 & Wrat \\
\hline PUREX & A550 & $296-A-10$ & 1. & 1 \\
\hline B-Plant & $\begin{array}{l}\text { B658 } \\
\text { B826 } \\
\text { B827 } \\
\text { B828 } \\
\text { B829 } \\
\text { B831 } \\
\end{array}$ & $\begin{array}{l}296-\mathrm{B}-22 \\
296-\mathrm{B}-23 \\
296-\mathrm{B}-24 \\
296-\mathrm{B}-25 \\
296-\mathrm{B}-26 \\
296-\mathrm{B}-27\end{array}$ & 24 & 24 \\
\hline \multirow{11}{*}{$\begin{array}{l}\text { East } \\
\text { Tank } \\
\text { Farms }\end{array}$} & E060 & $296-A-18$ & 26. & 4 \\
\hline & E061 & $296 \cdot A-19$ & 26 & 4 \\
\hline & E197 & 296-A-20 & 26 & 4 \\
\hline & E297 & $296-A-26$ & 26 & 4 \\
\hline & E272 & $296-A-28$ & $26^{*}$ & -4 \\
\hline & E903 & $296-A-30$ & 26 & 4 \\
\hline & EOIS & $296-A-41$ & 26: & 4 \\
\hline & EI48 & $296-A \cdot 43$ & 26. & 4 \\
\hline & $\mathrm{E} 044$ & $296-C-7$ & $26:$ & 4 \\
\hline & E209 & 296-P-31 & 26 & 4 \\
\hline & $\mathrm{E} 037$ & $296-P-41$ & $26:$ & 4 \\
\hline $242-A$ & E645 & $296-\mathrm{A}-21$ & 26 & 4 \\
\hline ETF & E036 & $296-E-1$ & 26. & 4 \\
\hline \multirow[b]{2}{*}{ 222-S Lab } & S264 & $296-\$-16$ & 26 & 4 \\
\hline & $\$ 289$ & $296-S-21$ & $26^{\circ}$ & 4 \\
\hline \multirow{5}{*}{$\begin{array}{c}\text { S-Plant } \\
\& \\
\text { U-Plant }\end{array}$} & 5006 & $291-5-1$ & 4 & 4 \\
\hline & $S 032$ & $296-S-2$ & 4 & 4 \\
\hline & $\$ 015$ & 296-S-7E & 4 & 1 \\
\hline & S016 & $296-5-7 \mathrm{~W}$ & 52. & 4 \\
\hline & U771 & $291-U-1$ & 4 & 4 \\
\hline \multirow{2}{*}{$\begin{array}{l}\text { Radiological } \\
\text { Counting Facility }\end{array}$} & $\mathrm{Y} 215$ & $\mathrm{H} 0-64-4230$ & 4 & 4 \\
\hline & $Y 214$ & $\mathrm{MO}-423$ & 4 & 4 \\
\hline \multirow{3}{*}{$T$-Plant } & T785 & 291-T-1 & 26 & 4 \\
\hline & TI54 & $296-T-7$ & 26 & 4 \\
\hline & 1786 & $296-T-13$ & 1 & 10 \\
\hline \multirow{2}{*}{ TRUSAF } & $T 783$ & $296-\mathrm{T}-11$ & 26 & 4 \\
\hline & $\mathrm{T} 784$ & $296-T-12$ & 26 & 4 \\
\hline \multirow{4}{*}{$\begin{array}{l}\text { West } \\
\text { Tank } \\
\text { Farms }\end{array}$} & w191 & $296 \cdot P-22$ & 26 & 4 \\
\hline & W096 & $296 \cdot 5 \cdot 18$ & 26. & 4 \\
\hline & W117 & 296-T-17 & 26 & 4 \\
\hline & Woo3 & 296-W-3 & 26 & 4 \\
\hline \multirow{2}{*}{ WSCF } & wolo & $696-W-1$ & 4 & 4 \\
\hline & Wol 1 & $696-W-2$ & 4 & 4 \\
\hline \multirow{5}{*}{$\begin{array}{l}\text { Plutonium } \\
\text { Finishing } \\
\text { Plant }\end{array}$} & 2913 & $296-Z-5$ & 26 & 4 \\
\hline & 2802 & $296-2-6$ & 26 & 4 \\
\hline & 2370 & $296-2 \cdot 10$ & 26 & 4 \\
\hline & 2814 & $296-Z-14$ & 26 & 4 \\
\hline & 2915 & $296-Z-15$ & 1 & 1 \\
\hline & & then & 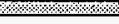 & \%8 \\
\hline & & Totals & 813. & 168 \\
\hline
\end{tabular}

a These record samples will be archived upon receipt. prior to analysis. Air \& Water Services will provide instructions regarding which samples to analyze or to composite and analyze, after each quarter. 


\section{Table A3 \\ Near-Facility Monitoringa CY-1998 Sample Analyses per Year}

\begin{tabular}{|c|c|c|c|c|c|c|c|c|c|c|c|}
\hline 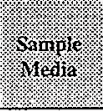 & xrea & 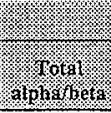 & 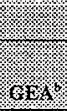 & 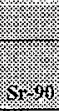 & 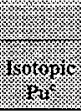 & 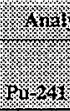 & 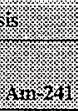 & 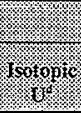 & 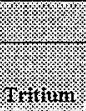 & \% & 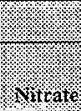 \\
\hline \multirow{8}{*}{ Air } & $100-\mathrm{B} / \mathrm{C}$ & 78 & 6 & 6 & 6 & & & 6 & & & \\
\hline & 100-D/DR & 104 & 8 & 8 & 8 & & & 8 & & & \\
\hline & $100-\mathrm{K}$ & 104 & 8 & 8 & 8 & 8 & & 8 & & & \\
\hline & $100-\mathrm{N}$ & 104 & 8 & 8 & 8 & & & 8 & & & \\
\hline & 200 & 884 & 70 & 70 & 70 & & 20 & 70 & & & \\
\hline & ERDF & 78 & 6 & 6 & 6 & & & 6 & & & \\
\hline & 300 & 26 & 2 & 2 & 2 & & & 2 & & & \\
\hline & $300-F F-01$ & 78 & 6 & & & & & 6 & & & \\
\hline \multicolumn{2}{|c|}{ Sample Totats } & 1456. & 114 & 108 & 108 & 8 & 20 & 114 & 0 & 0 & 0 \\
\hline 玨 & $8 \%$ & & (3) & 举 & 恶 & 社 & & 雨 & 4 & & \\
\hline \multirow{4}{*}{ Water } & 100 & & 10 & 10 & & & & & 10 & & \\
\hline & 200 & 36 & 36 & 36 & 36 & & & 36 & 12 & 162 & 12 \\
\hline & 300 & & & & & & & & & & \\
\hline & 400 & & & & & & & . & & & \\
\hline \multicolumn{2}{|c|}{ Sample Totals } & 36 & 46 & 46 & 36 & 0 & 0 & 36 & 22 & 162 & 12 \\
\hline & x & & & & & & & 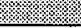 & & & \\
\hline \multirow{4}{*}{ Vegetation } & 100 & & 10 & 10 & 10 & & & 10 & & & \\
\hline & 200 & & 56 & 56 & 56 & & & 56 & & & \\
\hline & 300 & & 16 & 16 & 16 & & & 16 & & & \\
\hline & 400 & & 1 . & 1 & 1 & & & 1 & & & \\
\hline \multicolumn{2}{|c|}{ Sample Totals } & 0 & 83 & 83 & 83 & 0 & 0 & 83 & 0 & 0 & 0 \\
\hline \multirow{4}{*}{ Soil } & 100 & & 8 & 8 & 8 & & & 8 & & & \\
\hline & 200 & & 56 & 56 & 56 & & & 56 & & & \\
\hline & 300 & & 16 & 16 & 16 & & & 16 & & & \\
\hline & 400 & & 1 & 1 & 1 & & & 1 & & 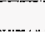 & \\
\hline \multicolumn{2}{|c|}{ Sample Totais } & 0 & 81 & 81 & 81 & 0 & 0 & 81 & 0 & 0 & 0 \\
\hline$\%$ & 4 & 4. & \% & \% & 9 & 8 & \% & 8 & 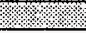 & 8 & 4 \\
\hline \multirow{3}{*}{$\begin{array}{l}\text { Estimated } \\
\text { NonRoutine } \\
\text { Samples }\end{array}$} & Air & & 25 & 25 & 25 & & 25 & 25 & & & \\
\hline & Soil & & 25 & 25 & 25 & & & & & & \\
\hline & Vegetation & . & 25 & 25 & 25 & & & 25 & & & \\
\hline \multicolumn{2}{|c|}{ Sample Totals } & 0 & 75 & 75 & 75 & 0 & 25 & 50 & 0 & 0 & 0 \\
\hline
\end{tabular}

a All routine Near-Facility Monitoring samples are identified by the Nxxx series or H001 through H1CO EDP codes. Special samples are identified as " $\mathrm{N}$ " monitoring samples on the chain-of-custody form. Specific EDP codes are not provided in this table since, no other samples share these EDP codes.

b Minimum GEA analysis results will be reported for Co-60, Ru-106, Sn-113, Sb-125, Cs-134, Cs-137, Ce-144, Eu-152, Eu-154, Eu-155, and any other radionuclides having positive peaks identified in the gamma spectrum.

Isotopic plutonium analysis will include $\mathrm{Pu}-238$, and $\mathrm{Pu}-239 / 240$ results.

d Isotopic uranium analysis will include U-238, U-234, and U-235 results. 


\section{DISTRUBUTION}

Number of copies

\section{ONSITE}

5 U.S. Department of EnergyRichland Operations Office

C. R. Briggs

S. E. Clarke A. $5-15$

J. B. Hall

A5 -15

D. C. Ward

A5- 15

Public Reading Room

5 Bechtel Hanford. Inc.
R. J: Landon
HO-02
D. W. Long
T7-05
J. E. Rugg
S3-21
J. G. Woolard
H0-17
J. P. Zoric
X5-53

2 Fluor Daniel Hanford, Inc.

S. M. Price

H6-23

D. G. Ranade

1 Lockheed Martin Services, Inc.

J. N. Diven

H8-41

1 SGN Eurisys Services Corporation

J. D. Criddle 
32 Waste Management Federal Services of Hanford. Inc.
A. K. Dasgupta (5)
S3-28
L. P. Diediker (20)
H6-36
E. M. Greager
H6-36
B. P. Gleckler
H6-36
H. K. Meznarich
S3-31
G. E. Millward
S3-28
J. L. Spahr
S3-31
R. A. Spohr
T3-02
W. R. Thackaberry
$\mathrm{T} 4-52$

5 Waste Management Federal Services, Inc., Northwest Operations

J. J. Dorian

H1-13

A. R. Johnson

H1-13

B. M. Markes

H1-13

S. M. Mckinney

H1-12

C. J. Perkins

H1 12

Central Files

B1-07 